\title{
EFFECT OF IRRIGATION LEVELS ON DISSOLVED ORGANIC CARBON SOIL DISTRIBUTION AND THE DEPTH MOBILITY OF CHLORPYRIFOS
}

\author{
Julio Junod ${ }^{1 *}$, Erick Zagal², Marco Sandoval², Ricardo Barra ${ }^{3}$, Gladys Vidal ${ }^{3}$, and Mario Villarroel ${ }^{4}$
}

\begin{abstract}
Water flows provided by irrigation systems may be associated with dissolved organic carbon (DOC) content in the soil solution and may modify the mobility of pesticides, such as chlorpyrifos (CHP). These compounds were analyzed under field conditions, evaluating their distribution in the soil profile under excessive irrigation in a Humic Haploxerand soil. The trial was carried out in soil columns located under the canopy of apple trees (Malus domestica Borkh.) in an orchard located in the Bío-Bío Region, Chile. The insecticide CHP was applied $120 \mathrm{~g} \mathrm{hL}^{-1}$, and later the natural run off was collected from the foliage to the columns. Surface irrigation was used as a control, the equivalent to $4 \mathrm{~L} \mathrm{~h}^{-1}$ weekly, plus two treatments over the columns of 6 and $8 \mathrm{~L} \mathrm{~h}^{-1}$ per pulse, respectively. Samples were obtained at three column depths: 0-5, 5-20 and 20-30 cm. The results showed that in spite of the fact that there was no interaction between depth and irrigation, a greater concentration of CHP was observed in the samples with greater water flow, with significant differences between the treatments at a depth of $20-30 \mathrm{~cm}$, which suggests some level of influence on vertical mobility. DOC shows stratification with greater concentrations at the surface and lower concentrations at depth, with significant differences between the superficial stratum $(0-5 \mathrm{~cm})$ and the lower strata $(5-20,20-30 \mathrm{~cm})$. These results are discussed in relation to explaining the movement of CHP in the soil profile.
\end{abstract}

Key words: pesticides, organic matter, volcanic soil.

\section{INTRODUCTION}

Chlorpyrifos (CHP) is a wide-spectrum contact phosphide-based insecticide, used especially for pest control in the fruit production (Scott et al., 2002). It is currently used in Chile with horticultural products such as celery (Apium graveolens L.), broccoli (Brassica oleracea L.), onions (Allium cepa L.), cauliflower (Brassica oleracea L.), artichokes (Cynara scolymus L.), lettuce (Lactuca sativa L.), radishes (Raphanus sativa L.), tomatoes (Lycopersicon esculentum L.), green beans (Phaseolus vulgaris L.), carrots (Daucus carota L. subsp. sativus (Hoffm.) Arcang.), potatoes (Solamun tuberosum L.), sugar beets (Beta vulgaris L. subsp. vulgaris), citric fruit (Citrus sp.), black currents (Ribes nigrum L.), kiwi (Actinidia deliciosa L.), pears (Pyrus communis L.), plums

\footnotetext{
'Universidad del Bío-Bío, Facultad de Ciencias de la Salud y los Alimentos, Casilla 474, Chillán, Chile.

*Corresponding author(jjunod@ubiobio.cl).

${ }^{2}$ Universidad de Concepción, Facultad de Agronomía, Av. Vicente Méndez 595, Casilla 537, Chillán, Chile.

${ }^{3}$ Universidad de Concepción, Centro EULA, Víctor Lamas 1290, Casilla 160 C, Concepción, Chile.

${ }^{4}$ Universidad de la Frontera, Facultad de Ingeniería, Francisco Salazar 01145, Casilla 54 D, Temuco, Chile.

Received: 30 November 2007.

Accepted: 07 May 2008.
}

(Prunus domestica L.), grapes (Vitis vinifera L. subsp. vinifera), peaches (Prunus persica L.) and nectarines (Prunus persica L. var. nectarina) (González, 2002).

However, use of this product is restricted in the USA, in particular with apples (Malus domestica Borkh.) (González, 2002) and its use with tomatoes has been banned completely (USEPA, 2008). This is because of the potentially toxic characteristics of the compound, as has been identified by the Environmental Protection Agency (EPA) and by several authors (Gollapudi et al., 1995; Hill et al., 1995; Richardson, 1995; Sherman, 1996; Lakew and Mekonnen, 1998; Lassiter et al., 1998; Bigbee et al., 1999; Crumpton et al., 2000; Axelrad et al., 2002).

According to the model suggested by Mackay (2001), the distribution of CHP in the environment is manifested mainly by $49.64 \%$ in the soil, $46.33 \%$ in sediments and $2.29 \%$ in water. In this context, the possible environmental impact of the compound and its metabolites can be expressed in the presence of organic compounds in bodies of water, influenced by the use of compounds like CHP in agricultural treatments and by the mobility of CHP. Several authors have described its presence in rivers and bays (Scott et al., 2002; Schulz, 2004). In this sense, the mobility of the compound plays a relevant role, which is expressed through volatilization (Whang et al., 1993; Rice et al., 2002; Wu et al., 2002), infiltration and 
percolation (Redondo et al., 1997; Gamon et al., 2003) or runoff (Schulz, 2001), the last two being associated with the soil and regulated by physical, physical-chemical and microbiological conditions that determine processes of transport, retention and transformation, respectively.

The chemical structure of the phosphide insecticide CHP is $O, O$-diethyl $O$-(3,5,6-trichloro-2-pyridinyl) phosphorothioate. The notable properties of this chemical agent are its solubility in water at $25^{\circ} \mathrm{C}$, which fluctuates between 0.44 and $2.90 \mathrm{mg} \mathrm{L}^{-1}$ (Stangroom et al., 2000; Rice et al., 2002; Kuang et al., 2003; Wolters et al., 2003); low constant of air-water partition $K_{\text {aw }}\left(0.5 \times 10^{-3}\right)$; high hydrophobicity $\log K_{\mathrm{ow}} 50.000$ (Racke, 1993); with a high possibility of chemical absorption in terms of organic $\mathrm{C}$ $K_{\text {oc }}\left(6.070\right.$ and $\left.9.930 \mathrm{~mL} \mathrm{~g}^{-1}\right)$ and absorption constant $\left(K_{\mathrm{d}}\right)$, which would indicate relative vertical immobility of the active ingredient (AI) (Chambers and Levi, 1992; Racke 1993; Flury, 1996; Haith et al., 2002). Consequently, CHP is considered to have a low infiltration potential in saturated and unsaturated soils, without evidence of being released to aquifers (Roy et al., 2001). Nevertheless, it has been demonstrated that in compounds with $K_{\mathrm{oc}} \geq 1000$ $\mathrm{mL} \mathrm{g}^{-1}$ in humid soils, the lixiviation of compounds such as CHP is facilitated by the phenomena of "preferential flow", where the solute is moved through a portion of available space in pores in the context of rainfall and/or the type of irrigation used (Flury, 1996; Arias-Estévez et al., 2008), thus resulting in AI in ground waters. Other evidence shows that chemical absorption to different fractions of soluble organic matter or coloids (Huang and Lee, 2001) can vertically mobilize compounds through the soil, termed co-transport, as well as the combination of the two processes (Williams et al., 2000). Herbert and Bertsch (1995) and Chantigny (2003) indicate that the capacity of dissolved organic matter (DOM) to facilitate the transportation of organic contaminants through the soil depends on the hydrophobicity of the organic contaminant and specific characteristics of the mobility of DOM. Consequently, the rapid transportation of fractions of DOM through the soil, coupled with strong absorption of non-ionic organic contaminants, can represent an important facilitator of transportation mechanisms. To this can be added the great quantity of micropores and aggregates in volcanic soils, which is expressed in a high capacity for water retention, with greater permeability than soils of a similar texture (Mallants et al., 1994). On the other hand, Müller et al. (2007) note the possible competition of the analytes for soil absorption sites.

CHP use is described in the literature as efficient and versatile from the productive point of view (González, 2002). However, from the environmental point of view its use is questionable (Gruber and Munn, 1998; Schulz, 2001; Scott et al., 2002; Schulz, 2004), centering studies on the determination of periods of shortfalls of crops and fruits, which is summarized in the agenda of pesticides of the Association of Producers and Importers of Phitosanitary Agricultural Products (AFIPA, 1998). On the other hand, there is evidence of extensive use of this compound in the Bío-Bío Region (SAG, 2002) given that CHP residues have been detected in water, soil and especially in sediments, for which CHP shows high affinity (Barra, 1993); a situation that coincides with periods of agricultural application of active compounds and increased irrigation, where the practice of surface irrigation is still common. Finding residues at the level of the basin would indicate a high use, possible excessive, of the pesticide, and a high mobility of the compound.

Considering CHP's high affinity for sediments, its physical-chemical characteristics and its possible association with fractions of organic matter $(\mathrm{OM})$, it is interesting to study the soluble fraction of $\mathrm{OM}$, such as dissolved organic C (DOC) present in volcanic soils, mainly because of their mobility and the consequent possible impact of CHP pollution associated with movement at this depth in the soil profile.

There are few studies of this soluble organic fraction (DOC) in volcanic soils (Müller et al., 2007), as a key factor for understanding the processes that act on the mobility of pesticides. Thus, the objective of this study was to establish CHP distribution at different soil depths after application of the insecticide in an apple orchard, while at the same time using different levels of irrigation, among them an excessive application that simulated surface irrigation. DOC distribution in this soil was also studied, seeking a possible in situ association between the two compounds resulting from the contact time of CHP in the soil profile.

\section{MATERIALS AND METHODS}

\section{Area of study}

The area of study was Nuble Province, Bío-Bío Region, Chile. The soil was Arrayán series, and classified as medial, amorphic, thermic Humic Haploxerands (Stolpe, 2006). Some of the chemical and physical characteristics of the soil under study are shown in Table 1 . The climate of this region is Mediterranean, with an average annual precipitation of $1000-1300 \mathrm{~mm}$ and an annual average temperature of $13.5-14.0^{\circ} \mathrm{C}$ (Del Pozo and Del Canto, 1999). Meteorological information for the period of the study was obtained from the Meteorological Station of Universidad de Concepción, Chillán campus, located approximately $200 \mathrm{~m}$ from the experimental site (Table 2). The data indicate that there was no precipitation during 
the study and that there were no important risks in terms of the volatilization of the CHP applied.

\section{Experimental site and treatments}

A 9-year-old fruit orchard with 3 ha was used for the assay, located at El Nogal Experimental Station of the Faculty of Agriculture of the Universidad de Concepción in the city of Chillán, ( $\left.36^{\circ} 34^{\prime} \mathrm{S}, 7^{\circ} 06^{\prime} \mathrm{W}\right)$. The orchard was planted in $5 \times 3 \mathrm{~m}$ blocks. Four trees from a row of 20 trees of the var. Scarlet were selected randomly. Each tree was considered a block (Figure 1). As a control, a buffer zone was established at a distance from the study area (approximately $120 \mathrm{~m}$ ). No risk of volatilization was detected, which was corroborated with analysis of foliage and soil from the buffer zone, where no quantifiable CHP residues were found (limit of quantification of the method $0.011 \mathrm{mg} \mathrm{L}^{-1}$ ). Some $1.98 \mathrm{~kg} \mathrm{ha}^{-1}$ of AI (Lorsban $50 \%$ $\mathrm{WP}^{\circledR}$, Dow AgroScience, Indianapolis, Indiana, USA) was applied to the orchard, which is equivalent to $120 \mathrm{~g} \mathrm{hL}^{-1}$, using a tractor driven piston pump, with the application of $\mathrm{AI}$ in the period of full fruit growth, considering a density of 667 trees ha-1.

The experimental design was randomized complete blocks with a factorial arrangement of $3 \times 3$, where the factors were three depths $(0-5,5-20$, and 20-30 cm) and three levels of water supplement ( 6 and $8 \mathrm{~L} \mathrm{~h}^{-1}$ of water by pulse irrigation for the treatments) and control of $4 \mathrm{~L} \mathrm{~h}^{-1}$ (the latter corresponding to surface irrigation practice). Irrigation was applied every 2 days, beginning the day of sampling, with a total of seven applications for the samples that remained the longest (treatments 6 and $8 \mathrm{~L} \mathrm{~h}^{-1}$ ). The control treatment with surface irrigation received a total of three applications over the course of the study, beginning the day before the sampling. Fifteen polyvinyl chloride (PVC) columns were used ( 0.30 long by $0.11 \mathrm{~m}$ in diameter) per tree (block), which were inserted into the soil by pressure under the canopy where the soil had a moisture level of $40.7 \%$, close to field capacity (Table 1). The columns were distributed as shown in Figure 1, generating in situ soil columns.

\section{Soil sampling and analysis}

The soil samples for each block were extracted in mornings (February 18, 21, 25, 28 and March 4, 2005, from the areas I, II, III, IV and V shown in Figure 1). A total of 12 columns were taken each time, which corresponds to 36 soil samples. The samples were packaged in polyethylene bags and sent to the soil laboratory of the Universidad de Concepción for DOC determination and to the Universidad del Bío-Bío for pesticide determination, maintaining the cold chain while the samples were transported by storing them in a cold chamber at $-18^{\circ} \mathrm{C}$ until their analysis. Soil samples were taken prior to pesticide application (17 February 2005), the results of which did not show CHP residues.

Residual CHP concentration and DOC content in each soil sample were measured, taking into account the effects independently of the volume of irrigation water, the depth in the soil column and the contact time of CHP in the soil profile, 0 ( $2 \mathrm{~h}$ after the application), 3, 7, 10 and 14 days. In this manner, the distribution over time of the insecticide in the soil profile was determined.

Table 1. Chemical and physical properties of the soil at the start of the study.

\begin{tabular}{|c|c|c|c|c|c|c|c|c|}
\hline Soil depth & $\mathbf{p H}^{1}$ & Humidity $^{2}$ & Sand $^{3}$ & Clay $^{3}$ & Lime $^{3}$ & $\operatorname{Org} C^{4}$ & $\mathrm{CC}^{5}$ & $\mathrm{BD}^{6}$ \\
\hline & & \multicolumn{6}{|c|}{$\%$} & $\mathrm{~g} \mathrm{~cm}^{-3}$ \\
\hline $0-30 \mathrm{~cm}$ & 5.9 & 40.69 & 49.4 & 28.0 & 22.6 & 3.36 & 37.7 & 1.18 \\
\hline
\end{tabular}

${ }^{1}$ In water $(1: 2.5)$ (ISO 10390,1994$) .{ }^{2}$ Weight loss at $105{ }^{\circ} \mathrm{C}$ (ISO 11465, 1993). ${ }^{3}$ Bouyoucos hydrometer method (Bouyoucos, 1962). ${ }^{4}$ Wet digestion (Metson et al., 1979). ${ }^{5}$ Field capacity at $33 \mathrm{kPa}$ and permanent wilting point at $1500 \mathrm{kPa}$ (Klute, 1986). ${ }^{6} \mathrm{Bulk}$ density. Clod method (Blake and Hartge, 1986).

Table 2. Daily meteorological parameters for the whole study period (February-March 2005).

\begin{tabular}{|c|c|c|c|c|c|c|c|c|c|c|c|c|c|c|c|}
\hline \multirow[b]{2}{*}{ Parameter } & \multicolumn{11}{|c|}{ February (days) } & \multicolumn{4}{|c|}{ March (days) } \\
\hline & 18 & 19 & 20 & 21 & 22 & 23 & 24 & 25 & 26 & 27 & 28 & 01 & $\mathbf{0 2}$ & 03 & 04 \\
\hline Average temperature ${ }^{\circ} \mathrm{C}$ & 20 & 22 & 21 & 22 & 23 & 21 & 22 & 24 & 22 & 21 & 17 & 19 & 18 & 23 & 21 \\
\hline Minimum temperature ${ }^{\circ} \mathrm{C}$ & 14 & 14 & 9 & 13 & 14 & 12 & 13 & 15 & 13 & 10 & 10 & 16 & 9 & 11 & 17 \\
\hline Maximum temperature ${ }^{\circ} \mathrm{C}$ & 32 & 31 & 32 & 33 & 32 & 31 & 33 & 33 & 32 & 29 & 21 & 25 & 30 & 33 & 26 \\
\hline Mean RH, \% & 71 & 50 & 53 & 47 & 49 & 54 & 45 & 43 & 48 & 60 & 73 & 68 & 69 & 60 & 66 \\
\hline Wind velocity, $\mathrm{km} \mathrm{h}^{-1}$ & 5 & 9 & 5 & 8 & 8 & 6 & 7 & 13 & 9 & 4 & 4 & 3 & 5 & 6 & 8 \\
\hline Precipitation, mm & 0 & 0 & 0 & 0 & 0 & 0 & 0 & 0 & 0 & 0 & 0 & 0 & 0 & 0 & 0 \\
\hline
\end{tabular}

Criteria for pesticide application: rain $<1.5 \mathrm{~mm} \mathrm{~d}^{-1}$, temperature: $<28{ }^{\circ} \mathrm{C}, \mathrm{RH}$ : relative humidity: 30 a $95 \%$, wind velocity: $<1.94 \mathrm{~m} \mathrm{~s}^{-1}$. 


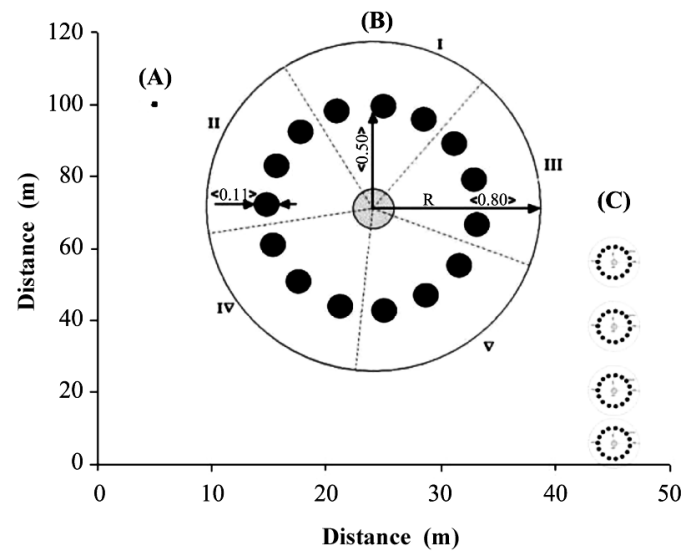

Figure 1. Experimental site: distribution of soil columns under canopy: (A) meteorological station; (B) zoom of one tree and distribution of 15 PVC columns (11 cm diameter); $R$ radius from trunk to $P V C$ column locations $(50 \mathrm{~cm})$ and radius limit of canopy shade $(80$ cm); I, II, III, IV and V correspond to five collecting times; (C) location and number of trees chosen at random.

A micro-extraction method, described by Steinwandter (1985) and Steinwandter (1990), was applied. The soil samples were sieved and pulverized in a mortar, $3 \mathrm{~g}$ were treated with $20 \mathrm{~mL}$ of the mixture 1:1 of acetone/dichloromethane and $2 \mathrm{~g}$ of sodium chloride and then homogenized with an agitator (Ultraturrax IKA-Labortechnick, Stanfen, Germany) for $1 \mathrm{~min}$. The homogenized samples were agitated using a magnetic bar for 5 min with $\mathrm{Na}_{2} \mathrm{SO}_{4}$ anhydrous and then left at rest to clarify the organic phase. An aliquot of $10 \mathrm{~mL}$ of this last phase was submitted to volume reduction to 0.5 $\mathrm{mL}$, using a rotavapor at $40{ }^{\circ} \mathrm{C}$ and $120 \mathrm{rpm}$, and then the reduced volume was washed in acetone three times. All the samples were determined in duplicate.

Gas chromatography (GC 6000 Vega, Series 2, Carlo Erba, Milan, Italy) was used with nitrogen phosphorus (NPD), an SGE BPX5 capillary column (5\% Phenyl equiv. Polysilphenylenesiloxane), with $25 \mathrm{~m}, 0.53 \mathrm{~mm}$ internal diameter (ID), $1 \mu \mathrm{m}$ thickness of film. The working conditions for the gas chromatography (GC) were: temperatures of the column $220^{\circ} \mathrm{C}$, injector $250{ }^{\circ} \mathrm{C}$, detector $270^{\circ} \mathrm{C}$; carrier flows $\mathrm{N}_{2} 4-5 \mathrm{~mL} \mathrm{~min}^{-1}$; pressure of $\mathrm{H}_{2} 80 \mathrm{kPa}$, air $120 \mathrm{kPa}$. As a calibration standard for CHP, the Chem Service standard of $100 \mu \mathrm{g} \mathrm{mL}^{-1}$ in isooctane was used (Certified Analytic Standard).

Organic $\mathrm{C}$ extraction was adapted according to Bolan et al. (1996) and Haynes (2000), for which $20 \mathrm{~mL}$ of distilled water was added to $20 \mathrm{~g}$ of dry soil and then agitated for $1 \mathrm{~h}$. It was centrifuged at $8000 \mathrm{rpm}$ for 10 min and subsequently filtered through Millipore HA filters, $0.41 \mu \mathrm{m}$ pore size. The filtrates were treated through humid combustion of the OM with a mixture of dichromate and sulphuric acid. The reduced chromate was then measured colorimetrically (Metson et al., 1979).

\section{Statistical analysis}

The data were submitted to analysis of variance (ANOVA) with 95\% significance, which was processed using SAS statistical software (SAS Institute, 1999). The Tukey test was used for comparison of means, with $95 \%$ significance. Verification of the suppositions of the ANOVA was done using the modified Shapiro Wilks test for the normality of the residues and the Levene test for homogeneity of variances, both with $95 \%$ significance (Steel et al., 1997). The data that did not comply with the suppositions were transformed under a natural logarithmic function $(\ln (x))$. To analyze the contact times $(0,3,7,10$ and 14 days) of CHP residues and DOC concentration throughout the soil profile, the data were processed using Sigma Plot software (Systat Software, 2004).

\section{RESULTS AND DISCUSSION}

\section{Distribution of CHP residues in the soil}

The ANOVA showed that there were no significant differences between the treatments (Irrigation 1 and Irrigation 2) in the first two levels of the soil profile in comparison to the control $(\mathrm{p}>0.05$, Table 3$)$. At the level of $20-30 \mathrm{~cm}$, the treatment with Irrigation 2 presented significant differences in comparison to the control $(\mathrm{p}<0.05)$. Upon analyzing the columns at the different depths of the soil profile (Table 4), it was observed that there were significant differences in the three depth levels, especially in the control and Irrigation 2. Although there is no interaction between depth and irrigation, it is important to note that the concentration of CHP residues shows a tendency to diminish in comparison to the initial surface residue $(0-5 \mathrm{~cm})$. In this sense, at a depth of 5-20 cm, there was a decrease of 25.7, 19.7 and $34.1 \%$ for the control and the two treatments (Irrigation 1 and Irrigation 2), respectively. Konda and Pásztor (2001) obtained a $33 \%$ decrease for the level of $0-5 \mathrm{~cm}$ at the end of 14 days, in a field study for soils from the Luvisol order in Hungary, in the context of precipitation (approximately $25 \mathrm{~mm}$ on average for the period of the study), a situation that would be in agreement with what was obtained in the treatment with greater irrigation in the present study. On the other hand, other authors have found that in tropical soils (Ultisol) CHP recovery at a depth of $0-10 \mathrm{~cm}$ was 23.6\% (Ciglasch et al., 2006); a situation that shows a high decrease of initially applied AI, associated with moisture and precipitation during the assay. 
At the depth of $20-30 \mathrm{~cm}$, the values of the decrease in AI were 5.6, 9.3 and $13.1 \%$ of the concentration found at the surface of the column, from the control to the treatment with the greatest flow, respectively, which shows some influence of excess water on the vertical movement of CHP. This ratifies what was expressed previously by Konda and Pásztor (2001) in relation to the descending mobility of CHP in the soil profile because of an excess of water.

Upon analyzing the CHP residues during the period under study (14 days), in relation to treatments and the depth level of $0-5 \mathrm{~cm}$, there were significant differences $(\mathrm{p}<0.05)$ between the time " 0 " ( $2 \mathrm{~h}$ after application $)$ in comparison to the four other time periods $(4,7,10$ and 14 days), showing a similar tendency of the CHP concentration curve to decrease in both treatments and the control (Figure 2A). However, at the $3^{\text {rd }}$ day after the application, both treatments showed a decrease in the deepest level of the soil profile in comparison to the control, after which both treatments maintained a similar dynamic in the process of dissipation. The dynamic indicates that at the surface level, excessive irrigation affects CHP in the short term, possibly associated with AI absorption by minerals or OM.

However, at the second level of depth of 5-20 $\mathrm{cm}$ (Figure 2B), in the first 3 days the control shows a greater concentration of CHP residues than in Irrigation 1 and Irrigation 2, which remained the same until the middle of the study period, presenting a dissipation curve characteristic of AI. It can also be observed that CHP concentration shows a tendency to increase slightly in the treatment with more irrigation water applied (Irrigation 2) between days 3 and 10 .

The highest concentration of CHP residues at a depth of 20-30 cm was observed in the two treatments (Irrigation 1 and 2) beginning with day 3 (Figure 2C). In contrast, beginning on day 7, Irrigation 1 and the control presented a similar tendency that disappears over time. On the other hand, in treatment 2, the residues tended to increase until day 10 and then leveled out until day 14 , similar to the tendency at the previous depth, which could show a possible impact of the increased volume of water on CHP concentrations. It appears that there are residues potentially able to continue moving in the column or stored at this level, which does not occur in Irrigation 1 and the control, given the levels of concentration at this depth after day 7. The possibility of CHP transport - which could be the product of preferential flow more associated with the characteristics of the soil (AriasEstévez et al., 2008) in this relatively homogeneous study (Table 3) or through complexes that can form among the $\mathrm{OM}$ in the soil (in dissolved form) and the pesticide (co-transport) (Müller et al., 2007), which could explain
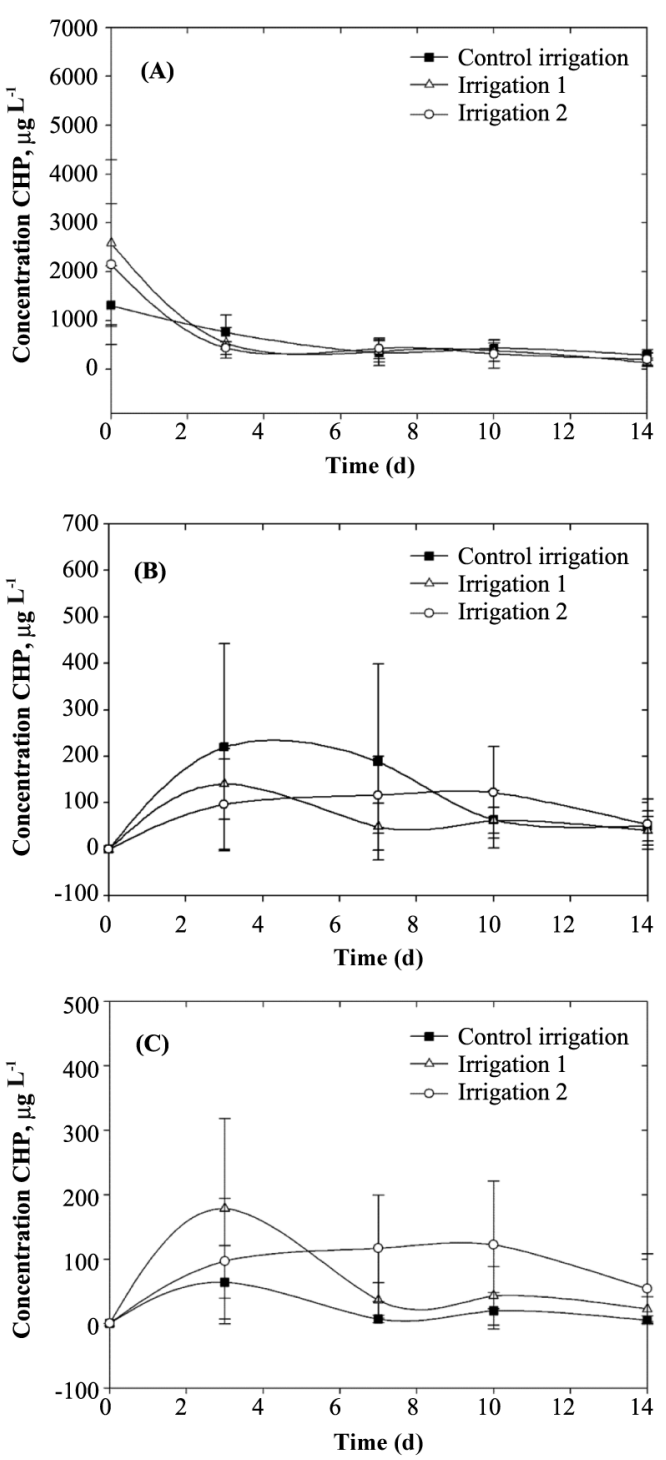

Figure 2. Distribution in the soil profile of the mean concentration and standard deviation of chlorpyrifos (CHP) residues over time, according to treatment at the depth levels: (A) 0-5 cm, (B) 5-20 cm, (C) 20-30 cm.

the CHP distribution observed in the soil profile in this study, where there was no significant interaction between irrigation and depth (see also the correlation of CHP and DOC indicated further on). An explanation that emerges for results is the competition of the two analytes for absorption sites, a mechanism that has been proposed by other authors (Müller et al., 2007) and which will be discussed in the following section.

\section{DOC distribution in the soil}

Despite the absence of an interaction between depth in the soil profile and irrigation, the ANOVA showed significant differences $(p<0.05$, Table 5$)$ between 
Table 3. Physical and chemical properties of the soil for the irrigation control and treatments during the study.

\begin{tabular}{|c|c|c|c|c|c|c|c|}
\hline Type of irrigation & Soil depth & $\mathrm{pH}^{1}$ & Humidity $^{2}$ & Sand $^{3}$ & Clay $^{3}$ & Lime $^{3}$ & $\operatorname{Org} \mathrm{C}^{4}$ \\
\hline & $\mathrm{cm}$ & & & & & $\pm \mathrm{SD}$ & \\
\hline \multirow[t]{3}{*}{ Control } & $0-5$ & 6.09 & $39.99 \pm 6.9$ & $43.21 \pm 8.9$ & $21.96 \pm 5.8$ & $34.32 \pm 4.7$ & $4.32 \pm 0.6$ \\
\hline & $5-20$ & 6.03 & $40.00 \pm 7.0$ & $43.61 \pm 9.0$ & $24.42 \pm 5.9$ & $32.32 \pm 4.6$ & $3.53 \pm 0.5$ \\
\hline & $20-30$ & 6.18 & $41.44 \pm 7.4$ & $44.04 \pm 9.8$ & $26.22 \pm 6.2$ & $39.87 \pm 4.3$ & $2.80 \pm 0.8$ \\
\hline \multirow[t]{3}{*}{ Irrigation 1} & $0-5$ & 6.11 & $41.92 \pm 5.1$ & $44.37 \pm 9.9$ & $21.44 \pm 7.2$ & $33.92 \pm 5.2$ & $4.56 \pm 0.6$ \\
\hline & $5-20$ & 6.11 & $41.36 \pm 4.3$ & $44.67 \pm 9.3$ & $23.96 \pm 5.8$ & $31.43 \pm 3.8$ & $3.43 \pm 0.6$ \\
\hline & $20-30$ & 6.10 & $43.25 \pm 5.7$ & $41.84 \pm 7.3$ & $27.35 \pm 6.1$ & $31.00 \pm 5.2$ & $2.82 \pm 0.9$ \\
\hline \multirow[t]{3}{*}{ Irrigation 2} & $0-5$ & 6.18 & $43.58 \pm 5.0$ & $45.06 \pm 13$ & $21.65 \pm 7.1$ & $32.57 \pm 6.5$ & $4.14 \pm 0.9$ \\
\hline & $5-20$ & 6.09 & $40.76 \pm 4.2$ & $42.76 \pm 8.3$ & $24.49 \pm 6.3$ & $32.32 \pm 4.4$ & $3.52 \pm 0.4$ \\
\hline & $20-30$ & 6.05 & $40.65 \pm 4.3$ & $41.40 \pm 7.7$ & $28.59 \pm 6.8$ & $30.61 \pm 4.1$ & $2.86 \pm 0.8$ \\
\hline
\end{tabular}

${ }^{1}$ In water $(1: 2.5)$ (ISO 10390,1994$) .{ }^{2}$ Weight loss at $105{ }^{\circ} \mathrm{C}$ (ISO 11465,1993$) .{ }^{3}$ Bouyoucos hydrometer method (Bouyoucos, 1962). ${ }^{4}$ Wet digestion (Metson et al., 1979). SD: Standard deviation.

Table 4. Mean concentration expressed on a dry basis for residues of chlorpyrifos (CHP) in $\mu \mathrm{g} \mathrm{L}^{-1}$ determined in the columns in relation to soil depth and treatment for the entire study period.

\begin{tabular}{lccc}
\hline & \multicolumn{3}{c}{ Mean CHP concentration CHP $\left(\boldsymbol{\mu g} \mathbf{L}^{-1}\right)^{*}$} \\
\cline { 2 - 4 } Depth, cm & $\begin{array}{c}\text { Control irrigation } \\
(\mathbf{n}=\mathbf{6 0})\end{array}$ & $\begin{array}{c}\text { Irrigation } \mathbf{~} \\
(\mathbf{n}=\mathbf{6 0})\end{array}$ & $\begin{array}{c}\text { Irrigation } \mathbf{2} \\
(\mathbf{n}=\mathbf{6 0})\end{array}$ \\
\hline $0-5$ & $629.85 \mathrm{aA}^{2}$ & $805.20 \mathrm{aA}$ & $707.10 \mathrm{aA}$ \\
$5-20$ & $161.10 \mathrm{bA}$ & $158.40 \mathrm{bA}$ & $241.10 \mathrm{bA}$ \\
$20-30$ & $35.53 \mathrm{cB}$ & $74.80 \mathrm{bAB}$ & $92.60 \mathrm{cA}$ \\
\hline
\end{tabular}

ANOVA carried out under transformation $\ln (x) . *$ Without interaction among the variables $(\mathrm{p}>0.05) .{ }^{1}$ Control irrigation $=4 \mathrm{~L} \mathrm{~h}^{-1}$ weekly. Irrigation $1=6$ $\mathrm{L} \mathrm{h}^{-1}$ by pulse; Irrigation $2=8 \mathrm{~L} \mathrm{~h}^{-1}$ by pulse. ${ }^{2}$ Vertically distinct lowercase letters and horizontally distinct uppercase letters indicate significant differences according to the Tukey test $(\mathrm{p}<0.05)$.

the initial concentration determined in the first two profiles studied $(0-5$ and $5-20 \mathrm{~cm})$ and the concentration determined in the last depth level $(20-30 \mathrm{~cm})$ in all the columns studied. This generates a stratification of the DOC, which could be a result of water flows, as indicated by Kalbitz et al. (2000) and more recently by Mertens et al. (2007), who suggest that the distribution of DOC in the soil profile is related mainly to water flows, suggesting

Table 5. Mean concentration expressed on a dry basis of the dissolved organic carbon (DOC) determined in the columns in relation to the soil depth and treatment for the entire study period.

\begin{tabular}{lccc}
\hline & \multicolumn{3}{c}{ Mean DOC concentration, $\mathbf{~ m g ~ L ~}^{-\mathbf{1}^{*}}$} \\
\hline $\begin{array}{l}\text { Depth, } \\
\mathbf{c m}\end{array}$ & $\begin{array}{c}\text { Control }^{\mathbf{1}} \\
(\mathbf{n}=\mathbf{6 0})\end{array}$ & $\begin{array}{c}\text { Irrigation } \mathbf{1} \\
(\mathbf{n}=\mathbf{6 0})\end{array}$ & $\begin{array}{c}\text { Irrigation } \mathbf{2} \\
(\mathbf{n}=\mathbf{6 0})\end{array}$ \\
\hline $0-5$ & $3.44 \mathrm{aA} \mathrm{A}^{2}$ & $2.78 \mathrm{aA}$ & $2.66 \mathrm{aA}$ \\
$5-20$ & $2.98 \mathrm{bA}$ & $2.32 \mathrm{bAB}$ & $2.45 \mathrm{bB}$ \\
$20-30$ & $1.65 \mathrm{bA}$ & $1.46 \mathrm{bA}$ & $1.51 \mathrm{bA}$ \\
\hline
\end{tabular}

ANOVA carried out under transformation $\ln (x)$. "Without interaction among the variables $(\mathrm{p}>0.05)$. ${ }^{1}$ Control irrigation $=4 \mathrm{~L} \mathrm{~h}^{-1}$ weekly. Irrigation $1=6 \mathrm{~L} \mathrm{~h}^{-1}$ by pulse; Irrigation $2=8 \mathrm{~L} \mathrm{~h}^{-1}$ by pulse. ${ }^{2}$ Vertically distinct lowercase letters and horizontally distinct uppercase letters indicate significant differences according to the Tukey test $(\mathrm{p}<0.05)$. a buffer effect of the soil on DOC concentrations. This change in DOC concentration is more notable by comparing the different irrigation levels by strata (Table 5); where there were significant differences at the level of $5-20 \mathrm{~cm}$, demonstrating that increased irrigation compared to the control treatment significantly influenced DOC concentration.

Observing the DOC dynamic over time and by depth level (Figure 3A), the concentrations show that the treatments and the control have a similar tendency at the strata $0-5 \mathrm{~cm}$, with a slight rise in the concentration for control from day 10 of the sampling. This confirms what was expressed by Mertens et al. (2007), who indicated that at the soil surface DOC mobilization is limited, with water flows being the major determinant in DOC distribution in the soil profile. This is observed mainly at the second depth level of 5-20 cm (Figure 3B), where the control shows a similar dynamic to those of the treatments (Irrigation 1 and 2) until the seventh day of sampling (four pulses already applied). Subsequently, the different levels of irrigation show different distributions of DOC. In contrast, at the level of 20-30 cm (Figure 3B) DOC concentrations continue the same cyclic 
tendency in the control and the two treatments. However, in general, samples from the treatments show lower DOC concentrations than the control. In effect, higher levels of applied water affect DOC concentration, with a tendency to decrease concentrations in the treatments compared to the control, that is, higher levels of water applied will affect DOC concentration, with a tendency of concentrations to decrease in comparison to the control, possibly because of mobilization, a situation that would respond to the irrigation pulses and possibly advances beyond the determination of the present study.
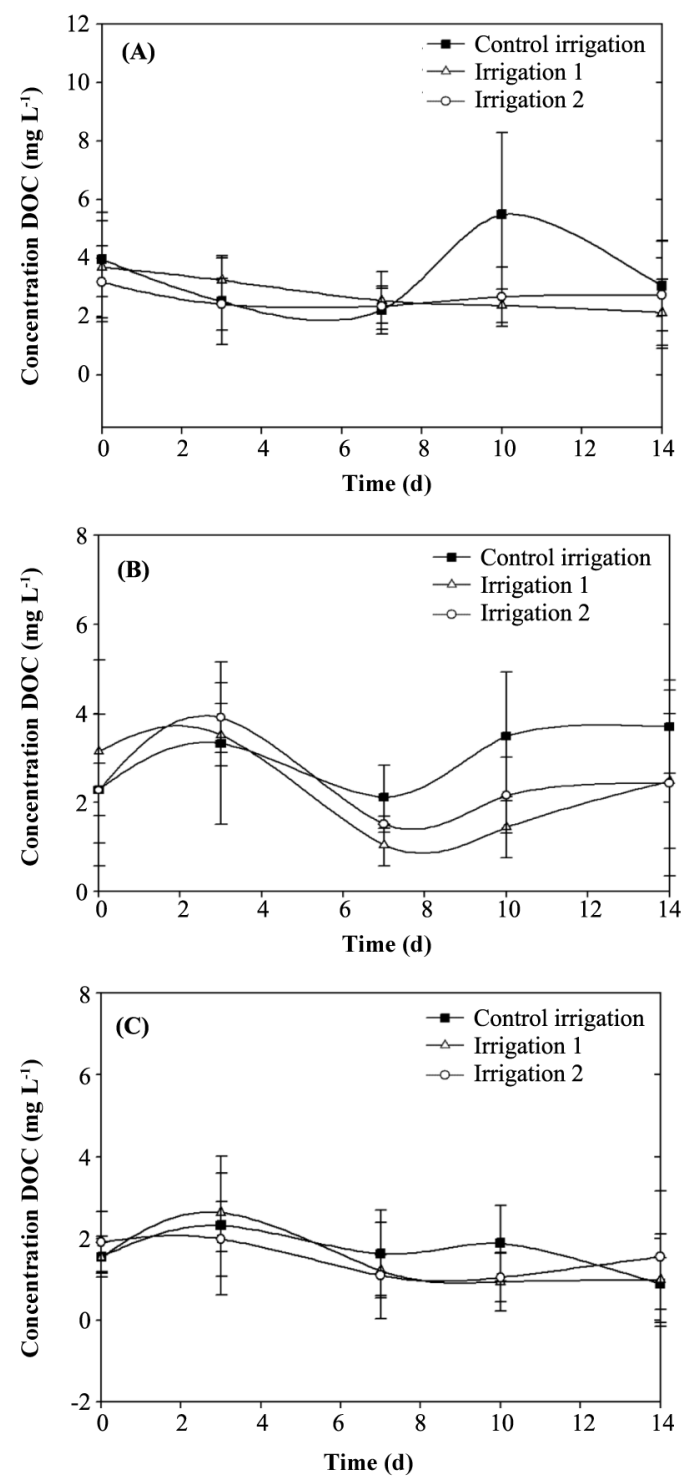

Figure 3. Distribution in the soil profile of the mean concentration and standard deviation for dissolved organic carbon (DOC) over time, according to treatment at the depth levels (A) 0-5 cm; (B) 5-20 cm; (C) 20-30 cm.

\section{Associativity of CHP and DOC in the soil}

Studies carried out by Huang and Lee (2001) determined a relationship between DOM and CHP residues and found a high affinity of CHP for DOM. In this study, the two analytes (CHP and DOC) did not correlate significantly. The correlation that was found was very low and related to the levels of water applied. For example, the control with an $\mathrm{R}=0.22$, Irrigation $1=0.11$ and Irrigation $2=0.04$. These results suggest a proportionally inverse relationship between the availability of DOC and CHP residues for the treatment with a greater flow of applied water (Figures 2A; $2 \mathrm{~B} ; 3 \mathrm{~A}$ and $3 \mathrm{~B}$ ). On the other hand, the majority of studies related to CHP show that surface movement (runoff) of this AI because of rainwater action. In contrast, there are few studies that deal with vertical movement of CHP in the context of rainfall in field conditions as Konda and Pásztor (2001) point out. Huang and Lee (2001) report that in field conditions it is probable that CHP remains in the upper part of the soil profile. Nevertheless, the results of the present study show a slight tendency to the vertical mobility of CHP, which was manifested in particular beginning on day 7 of the study, with greater emphasis on the treatments of Irrigation 1 and 2. Thus, and although more evidence is necessary (for example, the absorption coefficient of CHP or characteristics of DOM such as biodegradability and stability, size distribution, polarity and aromaticity and the hydrophobic fraction of DOM content), a possible explanation of our results is the competition between the two analytes for absorption sites in this type of soil, a hypothesis that has been proposed by other authors as well (Müller et al., 2007). DOC presents greater affinity for the soil than the CHP-DOC complex because of its higher polarity. Consequently, in complement to the proceeding hypothesis, the presence of DOC will retard CHP absorption by the soil, with which the transport of CHP to a lower soil level is facilitated, as was observed in this study.

To our knowledge, there are no reports of studies in volcanic soils in Chile that show variations in DOC, or studies of the tendencies of vertical mobilization of CHP at the depths studied in the present work. In general, there are few field studies researching the effect of irrigation with diverse effluents on the movement of pesticides (Müller et al., 2007).

\section{CONCLUSIONS}

The highest concentration of CHP residues was found at the greatest depth of the soil profile, with the treatment with the greatest pulse flow of water applied, which in this case can be compared to surface irrigation practices with deficient control of the water flow. The apparent mobilization of CHP through soil columns is limited, and 
its potential distribution in the soil profile is related to water flows and the availability of organic matter.

The distribution of DOC in the soil profile showed significant differences among the treatments (Irrigation 1 and 2) in comparison to the control, and a decrease from the surface to the greatest depth studied. The distribution of DOC content and CHP residues in the soil during the period of the study suggests a possible competition among these analytes for adsorption sites.

\section{ACKNOWLEDGEMENTS}

The present study is part of the doctoral thesis work in Environmental Sciences at the Centro EULA-Chile of the Universidad de Concepción. The authors thank the Research Department of the Universidad del BíoBío (DIUBB) for funding support, the Food Engineering Department of the Universidad del Bío-Bío, the Departments of Soil Science and Vegetal Production of the Faculty of Agriculture of the Universidad de Concepción for facilitating the use of experimental field and the Soil Laboratory, respectively.

\section{RESUMEN}

Efecto de niveles de riego sobre la distribución de carbono orgánico disuelto en el suelo y la movilidad en profundidad de clorpirifos. Los flujos de agua aportados por los sistemas de riego pueden estar asociados al contenido de carbono orgánico disuelto (DOC) en la solución del suelo y modificar la movilidad de pesticidas como el clorpirifos (CHP). Se analizan estos compuestos bajo condiciones de campo, evaluando su distribución en el perfil de suelo ante un exceso de riego en un suelo Humic Haploxerands. El ensayo se desarrolló en columnas de suelo ubicadas bajo la canopia de un huerto de manzanos (Malus domestica Borkh.) ubicado en la Región del BíoBío, Chile. Se aplicaron $120 \mathrm{~g} \mathrm{hL}^{-1}$ del insecticida CHP, posteriormente se recogió el escurrimiento natural desde el follaje hacia las columnas. Se aplicó riego tendido como control, equivalente a $4 \mathrm{~L} \mathrm{~h}^{-1}$ semanal, más dos tratamientos sobre las columnas de 6 y $8 \mathrm{~L} \mathrm{~h}^{-1}$ por pulso, respectivamente. Se obtuvieron muestras a tres alturas de columna $0-5,5-20$ y $20-30 \mathrm{~cm}$. Los resultados muestran que a pesar que no existe interacción entre profundidad y riego, se observa una mayor concentración de CHP en las muestras con mayor flujo de agua, con diferencias significativas entre los tratamientos a la profundidad de 20-30 cm, lo que sugiere algún nivel de influencia en su movilidad vertical. El DOC muestra una estratificación de mayor a menor concentración desde la superficie hacia la profundidad, con diferencias significativas entre la estrata superficial $(0-5 \mathrm{~cm})$ y las inferiores $(5-20,20-30 \mathrm{~cm})$. Estos resultados se discuten en relación a explicar la movilidad del CHP en el perfil del suelo.

Palabras clave: pesticida, materia orgánica, suelo volcánico.

\section{LITERATURE CITED}

AFIPA. 1998. Manual fitosanitario. 1997-1998. 450467 p. Asociación Nacional de Fabricantes e Importadores de Productos Fitosanitarios Agrícolas (AFIPA), Santiago. Imprenta Los Leones, Santiago, Chile.

Arias-Estévez, M., E. López-Periago, E. MartínezCarballo, J. Simal-Gándara, J.C. Mejuto, and L. García-Río. 2008. The mobility and degradation of pesticides in soils and the pollution of groundwater resources. Agric. Ecosyst. Environ. 123:247-260.

Axelrad, J.C., C.V. Howard, and W.G. Malean. 2002. Interaction between pesticides and components of pesticide formulations and in vitro neurotoxicity test. Toxicology 173:259-268.

Barra, R. 1993. Estimación del riesgo de contaminación de aguas superficiales por pesticidas en una cuenca experimental. 180 p. Tesis Doctoral en Ciencias Ambientales. Universidad de Concepción, Centro Eula-Chile, Concepción, Chile.

Bigbee, J.W., K.V. Sharma, J.J. Gupta, and J.L. Dupree. 1999. Morphogenic role for acetylcholinesterase in axonal outgrowth during neural development. Environ. Health Suppl. 107:81-87.

Blake, G., and K. Hartge. 1986. Bulk density. p. 363375. In A. Klute (ed.) Methods of soil analysis. Part I. Agronomy Monographs 9. American Society Agronomy, Madison, Wisconsin, USA.

Bolan, N.S., S. Baskaran, and S. Thiagarajan. 1996. An evaluation of methods of measurement of dissolved organic carbon in soils, manures, sludges and stream water. Commun. Soil Sci. Plant Anal. 27(13\&14):2723-2737.

Bouyoucos, G.J. 1962. Hydrometer method improved for making particle size analysis of soils. Agron. J. 54:464-465.

Ciglasch, H., J. Busche, W. Amelung, S. Totrakool, and M. Kaupenjohann. 2006. Insecticide dissipation after repeated field application to a Northern Thailand Ultisol. J. Agric. Food Chem. 54:8551-8559.

Crumpton, T.L., F.J. Seidler, and T.A. Slotkin. 2000. Developmental neurotoxicity of chlorpyrifos in vivo and in vitro: effects on nuclear transcription factors involved in cell replication and differentiation. Brain Res. 857:87-98. 
Chambers, J., and P. Levi. 1992. Organophosphates. Chemistry, fate and effects. p. 47-73. Academic Press, San Diego, California, USA.

Chantigny, M.H. 2003. Dissolved and water-extractable organic matter in soils: A review on influence of land use and management practices. Geoderma 113:357-380.

Del Pozo, A., y P. Del Canto. 1999. Áreas agroclimáticas y sistema productivo en la VII y VIII Regiones. $50 \mathrm{p}$. Ministerio de Agricultura, Instituto de Investigaciones Agropecuarias (INIA), Centro Regional de Investigación Quilamapu, Chillán, Chile.

Flury, M. 1996. Experimental evidence of transport of pesticides through field soils. A review. J. Environ. Qual. 25:25-45.

Gamón, M., E. Sáez, J. Gil, and R. Boluda. 2003. Direct and indirect exogenous contamination by pesticides of rice-farming soils in Mediterranean wetland. Arch. Environ. Contam. Toxicol. 44:141-151.

Gollapudi, B.B., L.A. Mendrala, and V.A. Linscombe. 1995. Evaluation of the genetic toxicity of the organophosphate insecticide chlorpyrifos. Mutat. Res. 342:25-36.

González, R. 2002. Degradación de residuos de plaguicidas en huertos frutales en Chile. Serie de Ciencias Agronómicas $N^{o}$ 4. 163 p. Universidad de Chile, Facultad de Ciencias Agronómicas. Ed. Ograma, Santiago, Chile.

Gruber, S., and M. Munn. 1998. Organophosphate and carbamate insecticides in agricultural waters and cholinesterase (ChE) inhibition in common carp (Cyprinus carpio). Arch. Environ. Contam. Toxicol. 35(3):391-396.

Haith, D., P. Lee, M. Clark, G. Roy, M. Imboden, and R. Walden. 2002. Modeling pesticide volatilization from turf. J. Environ. Qual. 31:724-729.

Haynes, R.J. 2000. Labile organic matter as an indicator of matter quality in arable and pastoral soils in New Zealand. Soil Biol. Biochem. 32:211-219.

Herbert, B.E., and P.M. Bertsch. 1995. Carbon forms and functions in forest soils. p. 63-88 In MacFee, W., and J.M. Felly (eds.) Soils Science Society of America, Madison, Wisconsin, USA.

Hill, R., S. Head, S. Baker, M. Gregg, D. Shealy, S. Bailey, et al. 1995. Pesticide residues in urine of adults living in United States: Reference range concentrations. Environ. Res. 71:99-108.

Huang, X., and L. Lee. 2001. Effects of dissolved organic matter from animal waste effluent on chlorpyrifos sortion by soil. J. Environ. Qual. 30:1258-1265.

ISO 11465. 1993. (E) Soil quality. Determination of dry matter and water content on a mass basisGravimetric method. International Organization for Standardization (ISO), Geneva, Switzerland.
ISO 10390. 1994. (E) Soil quality. Determination of pH. International Organization for Standardization (ISO), Geneva, Switzerland.

Kalbitz, K., S. Solinger, J.H. Park, B. Michalzik, and E. Matzner. 2000. Controls on the dynamic of dissolved organic matter in soils: A review. Soil Sci. 165:277304.

Klute, A. 1986. Water retention: Laboratory methods. p. 635-661. In A. Klute (ed.) Methods of soil analysis. Part I. Agronomy Monographs 9. American Society of Agronomy, Madison, Wisconsin, USA.

Konda, L., and Z. Pásztor. 2001. Environmental distribution of acetochlor, atrazine, chlorpyrifos and propisochlor under field conditions. J. Agric. Food Chem. 49:3859-3863.

Kuang, Z., L. McConnell, A. Torrens, D. Meritt, and S. Tobash. 2003. Atmospheric deposition of pesticides to an agricultural watershed of the Chesapeake Bay. J. Environ. Qual. 32:1611-1622.

Lakew, K., and Y. Mekonnen. 1998. The health status of northern Omo States Farm workers exposed to chlorpyrifos and profenofos. Ethiop. Med. J. 36:175184.

Lassiter, T., S. Padilla, S. Mortensen, S. Chanda, and B. Moser. 1998. Gestational exposure to chlorpyrifos: apparent protection of the fetus? Toxicol. Appl. Pharmacol. 152:56-65.

Mackay, D. 2001. Multimedia environmental models. The fugacity approach. 261 p. $2^{\text {th }}$ ed. Lewis Publishers, Boca Ratón, Florida, USA.

Mallants, D., M. Vanclooster, M. Meddahi, and J. Feyen. 1994. Estimating solute transport in undisturbed soil columns using time domain reflectometry. J. Contam. Hydrol. 17:91-109.

Mertens, J., J. Vanderborght, R. Kasteel, T. Pútz, R. Merckx, J. Feyen, and E. Smolders. 2007. Dissolved organic carbon fluxes under bare soil. J. Environ. Qual. 36:597-606.

Metson, A.J., L.C. Blakemore, and D.A. Rhoades. 1979. Methods for the determination of soil organic carbon: a review and application to the New Zealand soils. N.Z. J. Sci. 22:205-228.

Müller, K., G.N. Magesan, and N.S. Bolan. 2007. A critical review of the influence of effluent irrigation on the fate of pesticides in soil. Agric. Ecosyst. Environ. 120:93-116.

Racke, K.D. 1993. Environmental fate of chlorpyrifos. Rev. Environ. Contam. Toxicol. 131:1-150.

Redondo, M., M. Ruíz, and R. Boluda. 1997. Dissipation and distribution of atrazine, simazine, chlorpyrifos, and tetradifon residues in citrus orchard soil. Arch. Environ. Contam. Toxicol. 32:346-352. 
Rice, C., V. Nochetto, and P. Zara. 2002. Volatilization of trifluralin, atrazine, metolachlor, chlorpiryfos, I-endosulfan, b-endosulfan from freshly tilled soil. J. Agri. Food Chem. 50:4009-4017.

Richardson, R.J. 1995. Assessment of the neurotoxic potential of chlorpyrifos relative to other organophosphorus compounds: A critical review of the literature. J. Toxicol. Environ. Health 44:135-165.

Roy, W.R., I.G. Krapac, S.F. Chou, and F.W. Simmons. 2001. Pesticide storage and release in unsaturated soil in Illinois, USA. J. Environ. Sci. Health B 36:245-260.

SAG. 2002. Declaración de ventas de plaguicidas agrícolas enero a junio 1999. p. 69-80. Servicio Agrícola y Ganadero (SAG), Departamento de Protección Agrícola, Sub Departamento Plaguicidas y Fertilizantes, Santiago, Chile.

SAS Institute. 1999. SAS Release 8.1. SAS Institute, Cary, North Carolina, USA.

Scott, G., M. Fulton, E. Wirth, G. Chandler, P. Key, J. Daugomah, et al. 2002. Toxicological studies in tropical ecosystems: an ecotoxicological risk assessment of pesticide runoff in south Florida estuarine ecosystems. J. Agric. Food Chem. 50:44004408.

Schulz, R. 2001. Rainfall-induced sediment and pesticide input from orchards into Lourens River, Western Cape, South Africa: importance a single event. Water Res. 35:1869-1876.

Schulz, R. 2004. Field studies on exposure, effects, and risk mitigation of aquatic nonpoint-source insecticide pollution: A review. J. Environ. Qual. 33:419-448.

Sherman, J. 1996. Chlorpyrifos (Dursban)-associated birth defects: Report of for cases. Arch. Environ. Health 51:5-8.

Stangroom, S., J. Lester, and C. Collins. 2000. Abiotic behaviour of organic micropollutants in soils and the aquatic environment. A review: I. Partioning. Environ. Technol. 21:845-863.

Steel, R.G.D., J.H. Torrie, and D.A. Dickey. 1997. Principles and procedures of statistics: A biometrical approach. 356 p. $3^{\text {rd }}$ ed. McGraw-Hill, New York, USA.
Steinwandter, H. 1985. Universal 5-min on-line method for extracting and isolating pesticide residues and industrial chemicals. Fresenius J. Anal. Chem. 322:752-754.

Steinwandter, H. 1990. Contribution to the on-line method for extraction and isolation of pesticides residues and environmental chemicals. II. Miniaturization of the on-line method. Fresenius J. Anal. Chem. 336:8-11.

Stolpe, N. 2006. Descripciones de los principales suelos de la VIII Región de Chile. 84 p. Universidad de Concepción, Facultad de Agronomía, Departamento de Suelos y Recursos Naturales, Chillán, Chile.

Systat Software. 2004. Sigma Plot 9.0. Systat Software, San Jose, California, USA.

USEPA. 2008. 2,4-D, Bensulide, Chlorpyrifos, DCPA, Desmedipham, Dimethoate, Fenamiphos, Metolachlor, Phorate, Sethoxydim, Terbufos, Tetrachlorvinphos, and Triallate; Tolerance Actions. Federal Register Environmental Documents. US Environmental Protection Agency, Washington DC. Available at http://www.epa.gov/EPA-PEST/2008/ September/Day-17/p21736.htm (accessed 15 July 2004).

Whang, J., G. Schomburg, D. Glotfelty, and A. Taylor. 1993. Volatilization of fonofos, chlorpyrifos, and atrazine from conventional and no-till surface soils in the field. J. Environ. Qual. 22:173-180.

Williams, C.F., M. Agassi, J. Letey, W.J. Farmer, S.D. Nelson, and M. Ben Hur. 2000. Facilitated transport of napropamide by dissolved organic matter through soil columns. Soil Sci. Soc. Am. J. 64:590-594.

Wolters, A., V. Linnemann, M. Herbst, M. Klein, A. Schäffer, and H. Vereechen. 2003. Pesticide volatilization from soil: lysimeter measurement versus prediction of European registration models. J. Environ. Qual. 32:1183-1193.

Wu, L., R.L. Green, G. Liu, M.V. Yates, P. Pacheco, J. Gan, and S.R. Yates. 2002. Partitioning and persistence of trichlofon and chlorpyrifos in creeping bentgrass putting green. J. Environ. Qual. 31:889-895. 